\title{
Development of Teacher Research Competency Training System in Indonesia: A Need Analysis
}

\author{
Leonard $^{1,2, *}$, Basuki Wibawa $^{1}$ \\ ${ }^{1}$ Educational Technology Program, Universitas Negeri Jakarta, Indonesia \\ ${ }^{2}$ Math Education Program, Universitas Indraprasta PGRI, Indonesia
}

Received March 2, 2020; Revised April 4, 2020; Accepted April 19, 2020

Copyright $\odot 2020$ by authors, all rights reserved. Authors agree that this article remains permanently open access under the terms of the Creative Commons Attribution License 4.0 International License

\begin{abstract}
Training activities to improve the teachers' research competence in Indonesia still have not fulfilled the expected standards. The training has not been developed based on the expected long-term needs and objectives, namely teachers who are competent in conducting research. Training materials and materials have not been compiled based on adequate needs analysis. This research aims to know the principles of basic needs in the development of a training system to improve teachers' research competence. The methods used are research and development using the modified ADDIE development model in the first phase. The results of these studies are the principles in the development of training materials, which materialize to be an instructional goal, instructional objectives, success indicators, and participant's criteria. The general instructional goal set is "if a sample of the article is given, a group of competency enhancement trainees examines the teacher who will be able to complete 1 (one) research title in the form of a scientific article published in a national accredited scientific journal." The results of this need analysis are expected to be the basis of the development of a structured training system equipped with all other supporting training devices so that the goal to improve teachers' research competence can be achieved.
\end{abstract}

Keywords Need Analysis, Teachers' Research Competence, ADDIE

\section{Introduction}

The quality of education in Indonesia is still not in accordance with expectations and has not been able to fulfill the national educational objectives that have been established. One of the most influential factors is the priority of education that has not been paid attention to the teacher. Teachers are important elements in the success of educational objectives, where the quality variation of the teacher indicates the central role of the teacher in the performance of the education system [1], even from the first day of the learning process [2], [3]. However, the professional ability of the teacher is still lacking/not competent [4], teachers tend not to carry out their duties well, namely being agents of change in the learning process, to design and propose scenarios that can improve the quality of the learning process [5]. This fact shows that teachers tend to be not yet effective and have not yet oriented to student learning outcomes, as revealed by Klassen \& Kim [6] who said that teacher effectiveness refers to a set of within-person attributes-personality, motivation, beliefs, and dispositions- that interact with contextual factors (cultural, social, educational) to influence student outcomes.

Preliminary study results that researchers did against approximately 60 teachers in DKI Jakarta, showed that nearly 75 percent of teachers did not prepare the learning process well. Teachers tend to prepare learning by putting the material first to be taught, not learning objectives. Consequently, teachers do not make learning objectives as a basis for designing learning strategies, teaching materials, and also designing learning evaluation and assessment tools. Teachers also tend to teach in a monotonous method, i.e. not using creative, engaging methods of learning to inspire students to learn in class.

Low current competency of teacher is allegedly caused by a lack of interest in Indonesian society to become a teacher [7], [8]. There are students who do not want to be teachers after they graduate from the Faculty of Education, with the future reason being teachers still not promising. This fact confirms that enthusiasm has not grown in the teacher, but on the other hand the enthusiasm of the teacher (teacher enthusiasm) is the key to the effectiveness, high-quality learning, and describing the competence and motivation of the teacher [9]. It is very different from the conditions in Finland, which suggests that the competition 
in Finland is very strict to enter education majors [10]. The Faculty of Education is the most prestigious faculty than other faculties. This is due to that the salary of teachers in Finland is enormous. In addition, the Finnish state and people place teachers as respected professions, so those who bear the teacher's profession feel a prestige and pride of their own. Even Silander [11] says the high quality of teachers and teacher education is often considered to be the main reason for the success of Finnish students in the Programme for International Student Assessment (PISA).

Law number 14 of 2005 concerning Teachers and Lecturers article 20 point $\mathrm{b}$ revealed that in carrying out professional duties, teachers are obliged to improve and develop academic qualifications and competencies in an ongoing manner with the development of science, technology, and the arts. Based on this, teachers are required to continue to learn and increase their capacity as a teacher, so that they can perform their duties and responsibilities well. Silander [11] says that teachers are expected to continuously and systemically develop their own teaching methods and to refresh their professional skills. This condition is in accordance with the phenomenal sentences that are often pronounced, i.e. if someone wants to teach, he should not stop learning. The opinion reinforces the important message that teachers should continue to receive training and coaching aimed at improving their competence. Further Spear \& da Costa [12] says teacher training has become a common tool for addressing challenges within the educational sector.

Lasauskiene et al. [13] write general competencies of teacher which are applied in multiple teaching activities; hence, it may be stated that their development is one of the essential conditions predetermining teachers' abilities to adapt themselves to the changing world and assuring successful attainment of goals of education and implementation of educational activities. This opinion shows that teachers are required to continue to improve their competence so as to adapt to the changing world and achieve educational objectives as well as the success of learning. In general, in Indonesia, there are hardly any references that write about the teacher's competency improvement training. If we studied through the Google Scholar Index, we will find the majority of training organized for teachers is training on class action research [14]-[17], plus 1 article discussing the writing of scientific articles [18], although the article is more focused on how to use OJS, not technically writing scientific articles.

Education and training are an indispensable realm of educational technology, even part of educational technology. Januszewski \& Molenda [19] says that educational technology is the study and ethical practice of facilitating learning and improving performance by creating, using and managing appropriate technological processes and resources. This shows that education technology facilitates the learning process for anyone, not limited to students, but also teachers and other educators.
Education technology is expected to bring significant changes to the quality of the learning process, in this case, the education and training process for teachers in the school.

The importance of education and training was also expressed by Leo Pahkin, an education counselor from the Finnish National Education Agency, which revealed, "We are investing in education and training in the field of energy Who later produced innovation [10]". This condition is not yet able to be optimized in the coaching of teachers in Indonesia, which is evidenced by the absence of mature planning to conduct teacher training.

Theoretically and pragmatic, teachers actually have enormous authority in conducting learning, both in preparation, implementation, evaluation, and decision making. Knowledge of the learning process is absolutely owned by teachers. In fact, teachers are expected to produce innovations in learning, whose goal is to ultimately improve the quality of learning in the classroom. Improved learning quality in terms of the development of learning innovations can be generated through research and development activities.

In line with this fact, teachers are further expected to be competent in research, aiming at producing innovations in learning. Alomari et al. [20] even write that the teacher is an important asset in the study. However, the fact that the teacher does not have enough competence in carrying out research. This fact is seen from the preliminary study results that researchers did before, i.e. nearly 70 percent of teachers surveyed have not yet had the correct knowledge of the concept of problems and research. In fact, nearly 90 percent of teachers have never done research activities and eventually resulted in nearly 100 percent of teachers never doing publications on the results of the research. For that reason, teachers should be encouraged to engage in research and participate in the practice of learning in the classroom with the aim of enhancing student learning achievement [21].

The importance of research activities for teachers is expressed by Hammersley [22], who states, "educational research should be an integral part of the work of teachers in schools rather than an activity carried out on schools by outsiders". This suggests that research is actually an integral part of a teacher's work. That is, by conducting research, a teacher can continue to improve the quality of learning in its class over time. Cheruvu [23] states, "Yet teacher research - systematic data collection and analysis of a problem of practice-is helpful for improving one's practice, gaining a deeper understanding of students' perspectives and needs, and, ultimately, improving students' learning." From this understanding, it appears that research will result in meaningful learning that will eventually improve the quality of student learning outcomes.

If analyzed, the low quality of learning is a result of weak research activities undertaken by teachers, thus never 
producing innovations in learning. In other words, research plays an important role in the overall learning activities and, of course, can indirectly improve the quality of teachers, which leads to improved student learning outcomes. Research is directly able to produce innovations in learning development, media development, teaching materials development, and also curriculum development. It is supported by the opinions of Souto-Manning (Cheruvu, [23]) stating that teacher educators must engage in teacher research with three goals in mind: to transform the self, to transform the curriculum, and to transform teaching in teacher education. These goals can collectively lead to a transformation of society.

Based on the previous description, it can be said that training for the improvement of teachers ' competence does important research to do. Training should be carried out based on the appropriate needs analysis, especially for the purpose of producing scientific publications, so that it can be a proud portfolio for teachers. This research will illustrate the need for analysis as a basis to develop an effective training system for the improvement of teacher competence.

\section{Methods}

The research method used is a development method, which is a modified ADDIE development model. ADDIE's model of development as a model is chosen as the main model because in theory it is devoted to developing training and also more comprehensive to develop every needed part in systematic training. The modifications in question include the other development elements that are ARCS, ASSURE and Dick \& Carey. The emphasis of this model is on the strategy of implementing training, namely the application of collaborative learning and collaborative research in the implementation of learning, which is also modified by considering the element development of ARCS strategy (Attention, Relevance, Confidence, Satisfaction) in the learning and involvement of participants as an adult learner. Richey \& Klein [24] writes the design and development knowledge base has six major components, (a) learners and how they learn, (b) the context in which learning and performance occur, (c) the nature of content and how it is sequenced, (d) the instructional strategies and activities employed, $€$ the media and delivery systems used, and (f) the designers themselves and the processes they use. In this way, we can determine the relevance of context-specific findings for other teaching and learning environment as well as identify new general principles of design, development, and evaluation. In principle, there is no ultimate model or the best model. However, there are only models that fit the specific needs of each activity that will be developed, both for classical learning in classes on the education process at elementary, junior high school, and college level, or special learning. Such training is held for adults in the framework of refreshment and improvement of scientific capacity.

This research uses only 1 part of the ADDIE model, which is the analysis. This stage of analysis, including the need for analysis activities, analysis of tasks, program and rational training materials, as well as the analysis of learners. The entire stage of this analysis will be some guidelines in formulating general instructional objectives, which is the final goal of developing a particular learning system. Researchers are trying to find important things that become the need and basis for the development of training systems related to teacher research competencies. Its main targets are general instructional goal design, special instructional objectives, success indicators, and important training-related principles to be developed, such as essential material and prospective participant criteria.

3. Results and Discussion

\section{Results}

Needs analysis is done through interviews to education and learning experts, including Prof. Zulkardi (Sriwijaya University Mathematics Education Expert), Prof. Sumaryoto (Rector of Indraprasta PGRI University), Prof. Supardi U.S. (Chief of General Officer of PGRI), Prof. Muljani A. Nurhadi (graduate lecturer of Indraprasta PGRI University), Dr. Rully Charitas Indra Prahmana (lecturer at Ahmad Dahlan University), and Dr. Somakin (Sriwijaya University lecturer).

Things excavated from experts aim to obtain information in order to set general instructional objectives and specific instructional objectives, training important principles for teachers, materials that need to be given, and provisions on the trainees ' criteria. That is, all the things developed in this research are based on the analysis of needs done so that there is a complete and clear guide. The results of further analysis are concluded to be general instructional objectives, special instructional objectives, and training material distribution. Important findings as a result of the analysis of the needs of the experts are as follows: 1) training activities are developed to meet the needs of teachers in developing learning innovations, 2) the methods developed in the training should be case-based and the experience faced by each teacher at school, 3) The trainees need to be selected based on specific criteria that support the application of technology, namely familiar in computer use, the Internet, and MS Word, 4) participants need to be grouped and conduct research conducted collaboratively, 5) the strategy used is to provide real examples of published research articles so that the implementers must provide access to qualified scientific journals, 6) This training activity must produce a real product and can be felt directly by the trainees, and 7) description of the material that should be given in this training include: a) research concept, b) determination of 
problems, c) search theory, d) instrument design, e) analysing the data of research results, and f) the design of scientific articles.

\subsection{Instructional Goal (IG)}

The instructional goal is a long-term goal or the ultimate goal of a developed training activity. The general instructional goal setting is based on the results of the need analysis. The general instructional objective set is "if a sample of the article is given, a group of competency enhancement trainees examines the teacher will be able to complete 1 (one) research title in the form of a scientific article published in a national accredited scientific journal."

\subsection{Instructional Objectives (IO)}

Based on the analysis of the needs and analysis of general instructional objectives, the specific instructional objectives and success indicators are further formulated, which will be used as a guide for developing devices Support of training. The specific instructional objectives and indicators of success include.

IO 1. Participants are able to use the internet to access and download articles from national journals (accredited or not accredited) and international journals (international or reputable international), with indicators: a) the participant has an email account at gmail.com, b) participants have an account at scholar.google.com, c) participants are able to understand the characteristics of published scientific journals in the world, d) participants are able to access and register in the Open Journal System of the national journals (accredited or not accredited) and or international journal (International or reputable international), e) participants are able to download at least 5 articles from each National Journal that are accessed (at least access 3 national journals), f) participants are able to access scimagojr.com and scopus.com to obtain information regarding a reputable international journal list, and g) participants are able to download a minimum of 5 articles from each reputable international journal accessed (at least access 3 international journals).

IO 2. Participants are able to use Mendeley application to manage scripts and to conduct scientific article citations, with indicators: a) participants are able to install Mendeley on his laptop, b) participants are able to manage the article script that is input in Mendeley (article input, create a folder, delete a script, merge similar articles, synchronize the script, etc.), c) participants are able to correct the metadata to generate citations that correspond to the quote rules, d) participants are able to install Mendeley Plugin in MS Word, and e) participants were able to use Mendeley to write a quotation in the article being designed.

IO 3. Participants are able to understand the concepts of problems and research methodology, with indicators: a) participants understand the concept of research issues and able to establish research problems to be raised, b) participants understand various research methods and c) participants are able to set the research title.

IO 4. Participants understand and master the experimental research concept, with indicators: a) participants understand the concept of experimental research, b) participants understand the terms and conditions of the implementation of experimental research, c) participants are able to carry out experimental research process, and d) participants understand and master the data analysis techniques in experimental research.

IO 5. Participants are able to understand and use various methods of learning in the implementation of research, with indicators: a) participants understand various methods of learning, including the syntax of each learning method and b) participants, can determine the learning method used in the research activities to be implemented.

IO 6. Participants are able to design a learning plan, with indicators: a) participants understand the latest standard of the learning plan and b) participants are able to design the learning plan.

IO 7. Participants capable of understanding instrument concepts and designing HOTS-based validated research instruments, with indicators: a) participants understand the concept of research instruments, b) participants are able to determine the right type of instrument in study, c) participants are able to design HOTS-based research instruments, and d) participants are able to validate the research instrument designed.

IO 8. Participants are able to understand the concept of sampling techniques, with indicators: a) participants understand the concept of population and samples, b) participants are able to determine the right sample techniques according to the type of research, and c) participants are able to determine the number of samples to suit the needs.

IO 9. The participant is able to understand the statistical analysis concept and able to conduct Data processing results of research, with indicators: a) participants are able to analyze the quality of research instrument, b) participants are able to test data analysis requirements, c) participants are able to test the assumption of classic violations, and d) participants are able to conduct hypothesis testing.

IO 10. Participants are able to understand scientific article planning steps, with indicators: a) mastering the standards of scientific article writing, b) determine the right title, c) designing the right abstract, d) designing a good introduction and describing as many references as possible to the research problem, e) designing the research method part well, f) designing the research results section well, g) designing a good discussion section and using as many references as possible from the results of similar research, $h$ ) designing the cover or conclusion well, and i) designing a library list well. 


\subsection{Trainees Criteria}

Trainees are an important element in training activities. Expert feedback shows that not all teachers can be trainees because there are certain criteria that teachers must fulfil to be trainees. This is intended for training to run more effectively and efficiently so that the training results can be optimized according to the objectives set before. The criteria of special participants of the trainees are as follows: 1) have a commitment to follow the training from start to finish, 2) have the commitment to complete each task and target to be training objectives, 3) familiar with Microsoft Word, 4) is familiar with the Internet, and 5) is under 45 years old.

\section{Discussion}

This research has successfully formulated a number of basic principles in the development of training systems for the improvement of teachers' competence in research, namely instructional goal(s), instructional objective(s), success indicators, and criteria of prospective trainees. This instructional goal design can then be a guideline for developing a training system aimed at achieving that instructional goal. The teacher's competency improvement training system in conducting this research is expected to fulfill the needs of teachers in Indonesia, especially in terms of researching competencies. Until now, there has been no training system in published scientific articles related to research competencies for teachers. If any, research on teacher competence is more about learning process [25], [26], [27], [28], the use of various media learning [29], [30], [31], and evaluation of learning [32]. As has been outlined in the previous section that there have not been any scientific writings related to the need for analysis of teachers' competence in conducting research, making it difficult to compare the results of these studies with similar scientific writings. However, studies discussing the competence in conducting more research in the form of textbooks that do not discuss the methods of research in general, meaning that it is not specific in order to improve the competency of teachers in conducting research. This fact shows that the training systems developed are new to the competency of teachers, namely training to improve the competency of teachers in conducting research.

Based on the results of the need analysis, the instructional goal(s) that must be achieved by the participant is to publish scientific articles in an accredited national journal. This indicates that training should be implemented based on performance and not merely knowledge or understanding. The success of the trainees published scientific articles on a quality journal, indicating that the participants had succeeded in mastering important aspects of research, not only in the information level but also technically. Competence of conducting research is a synergy of various technical aspects, such as the ability to use the internet, search and find quality references, master how to send scientific articles, master the concept of research, the ability to process data, and interpret research results.

The competence of designing scientific articles must also be supplemented by various other basic capabilities, so this research formulates a variety of special instructional objectives, as a technical description of the instructional goal(s) established. This particular instructional purpose explains what trainees must master to achieve the ultimate goal of a training system. The basic ability to be studied by technically trained participants is the ability to use various applications supporting scientific publications, namely the use of Mendeley and internet use in research. This becomes absolutely mastered considering that almost all of the journals in the world have used online concepts in the process of managing the script. On the basis of the complexity of this ability, the research also recommends that there are criteria that must be fulfilled by prospective trainees, especially computer mastery and internet use in everyday life. The determination of this criterion is intended for training to run conducive and smooth and can meet the instructional goal(s) that have been established. The preparation of this participant is due to the rapid development of computer and internet technology [33], [34], so it takes prospective participants to adapt to the change.

The results of this need analysis illustrate that training should be implemented in several stages that synergize each other. That is, each stage becomes the basis for mastering the next stage, so hopefully, the trainees can master the material comprehensively and produce a product of scientifically worthy articles published in an accredited journal. As previously described, there have been no research results related to the training system to improve teachers' competence in research, and there are no devices that fully accommodate similar training. To that point, this article can be a major reference in the development of similar research, so that increasing the competency of teachers can occur gradually. There are many specific things developed in this training system and are important elements of the overall training material, including preparation materials such as email use, Google Scholar account registration, account registration in OJS, search internationally reputable references, even how to submit articles into scientific journals. Another thing that is also developed according to expert input is the fact that this training system has accommodated expert advice, which is to incorporate materials on the planning of HOTS so that teachers can develop good questions and can make it as a research instrument of the research activities that will be performed at the next time.

The results of this need analysis are expected to be a good start for teacher training development, which will eventually be able to improve the teacher's performance in 
learning. Hopefully, there will be changes in learning objectives, from knowledge-based learning and skills to ability-based learning and literacy [35]. Based on the needs analysis that produces instructional goal(s) and instructional objectives, these results need to be recommended for a structured training system. Carefully designed training based on the results of analysis needs is expected to realize the objectives that have been established. This recommendation can be done by various parties, who have a passion to improve the competency of teachers in conducting research. It would be expected to emerge various new strategies in training more effectively to achieve general instructional objectives and ensure that the trainer must have the proper mastery of technology and content in order to provide training in the right way [36]. Thus it is expected to reach the objectives of national education through increased competency of teachers [37].

\section{Conclusions}

This research has succeeded in formulating the basic principles necessary to develop a training system for increasing the competency of teachers in conducting research. General instructional objectives, special instructional objectives, and criteria of prospective trainees are expected to be guidelines for developing other devices needed in training, such as training modules, presentation materials, video learning, and so forth. This research is the beginning of a larger design process and what resulted from this research is a new thing that is still rarely found in previous scientific publications.

\section{Acknowledgements}

We thank all the parties who help in writing this article, especially to the speakers, Prof. Dr. Zulkardi, Prof. Dr. Sumaryoto, Prof. Dr. Supardi U.S., Dr. Rully Charitas Indra Prahmana, Dr. Hasbullah, Dr. Andri Suryana, and Dr. Somakin, who have given us a lot of feedback.

\section{REFERENCES}

[1] A. Bouguen, "Adjusting content to individual student needs: Further evidence from an in-service teacher training program," Econ. Educ. Rev., vol. 50, pp. 90-112, 2016, doi: 10.1016/j.econedurev.2015.12.004.

[2] J. Dietrich, A. L. Dicke, B. Kracke, and P. Noack, "Teacher support and its influence on students' intrinsic value and effort: Dimensional comparison effects across subjects," Learn. Instr., vol. 39, pp. 45-54, 2015, doi: 10.1016/j.learninstruc.2015.05.007.

[3] D. L. Roorda, H. M. Y. Koomen, J. L. Spilt, and F. J. Oort, "The influence of affective teacher-student relationships on students' school engagement and achievement: A meta-analytic approach," Rev. Educ. Res., vol. 81, no. 4, pp. 493-529, 2011, doi: 10.3102/0034654311421793.

[4] A. N. Aeni, "Menjadi guru SD yang memiliki kompetensi personal-religius melalui program one day one juz (ODOJ)," Mimb. Sekol. Dasar, vol. 2, no. 2, pp. 212-223, Oct. 2015, doi: http://doi.org/10.17509/mimbar-sd.v2i2.1331.

[5] M. Gracenea et al., "New Roles and Learning Scenarios in the Training of the Novice Teachers at the University of Barcelona," Procedia - Soc. Behav. Sci., vol. 196, pp. 96-99, 2015, doi: 10.1016/j.sbspro.2015.07.017.

[6] R. M. Klassen and L. E. Kim, "Selecting teachers and prospective teachers: A meta-analysis," Educ. Res. Rev., vol. 26, no. December 2018, pp. 32-51, 2019, doi: 10.1016/j.edurev.2018.12.003.

[7] H. Harun, "Minat, motivasi dan kemahiran mengajar guru pelatih," J. Pendidik. Malaysia, vol. 31, pp. 83-96, 2006.

[8] H. Widyastono, "The interest to become a teacher, the knowledge of the evaluation on learning achievement, and the quality of curiculum document designed by the teacher," J. Pendidik. dan Kebud., vol. 19, no. 2, pp. 222-235, 2013.

[9] I. Burić and A. Moè, "What makes teachers enthusiastic: The interplay of positive affect, self-efficacy and job satisfaction," Teach. Teach. Educ., vol. 89, 2020, doi: 10.1016/j.tate.2019.103008.

[10] M. Chatib, Gurunya Manusia. Bandung: Mizan Pustaka, 2014.

[11] T. Silander, "Pedagogical environments - Case Finland," Form. Insegn., vol. 11, no. 4, pp. 51-62, 2013, doi: 10746/-fei-XI-03-13_02.

[12] A. M. Spear and R. B. da Costa, "Potential for transformation? Two teacher training programs examined through a critical pedagogy framework," Teach. Teach. Educ., vol. 69, pp. 202-209, 2018, doi: 10.1016/j.tate.2017 .10 .013 .

[13] J. Lasauskienè, A. Rauduvaite, and M. Barkauskaite, "Development of general competencies within the context of teacher training," Procedia - Soc. Behav. Sci., vol. 191, pp. 777-782, Jun. 2015, doi: 10.1016/j.sbspro.2015.04.525.

[14] S. Wiganda, "Pelatihan penelitian tindakan kelas bagi guru-guru se-Jakarta Timur," J. Sarwahita, vol. 11, no. 1, pp. 1-7, 2014, doi: 10.21009/sarwahita.111.01.

[15] P. Jana and B. Pamungkas, "Pelatihan penelitian tindakan kelas bagi guru SD Negeri Guwosari," Abdimas Dewantara, vol. 1, no. 1, pp. 39-46, 2018, doi: 10.30738/ad.v1i1.2289.

[16] E. Susanti and D. Hartanto, "Peningkatan kompetensi guru melalui penerapan penelitian tindakan kelas (PTK) dalam pendidikan Islam," J. Potensia, vol. 14, no. 1, pp. 151-174, 2015.

[17] H. Fitria, M. Kristiawan, and N. Rahmat, "Upaya meningkatkan kompetensi guru melalui pelatihan penelitian tindakan kelas," Abdimas Unwahas, vol. 4, no. 1, pp. 14-25, 2019, doi: http://dx.doi.org/10.31942/abd.v4i1.2690.

[18] T. Kurniawati and M. K. Siwi, "Peningkatan kompetensi guru dalam penulisan artikel dan publikasi pada open journal system (OJS)," J. EcoGen, vol. 2, no. 4, pp. 596- 
600,2019

[19] A. Januszewski and M. Molenda, Educational Technology: A Definition with Commentary. New York: Taylor \& Francis Group, 2013.

[20] M. A. Alomari, N. A. Al-sheyab, O. F. Khabour, and K. H. Alzoubi, "Assent and consent in adolescent research: Teachers' perspectives from a developing country," Heliyon, vol. 6, pp. 1-5, 2020, doi: 10.1016/j.heliyon.2019 .e03116.

[21] B. Cooper and B. Cowie, "Collaborative research for assessment for learning," Teach. Teach. Educ., vol. 26, no. 4, pp. 979-986, 2010, doi: 10.1016/j.tate.2009.10.040.

[22] M. Hammersley, "On the teacher as researcher," Educ. Action Res., vol. 1, no. 3, pp. 425-445, 1993, doi: 10.1080/ 0965079930010308 .

[23] R. Cheruvu, "Focus on teacher as researcher: Teacher educators as teacher researchers: Practicing what we teach," Child. Educ., vol. 90, no. 3, pp. 225-228, May 2014, doi: 10.1080/00094056.2014.911636.

[24] R. C. Richey and J. D. Klein, Design and Development Research. New York: Routledge, 2007.

[25] L. Bürgener and M. Barth, "Sustainability competencies in teacher education: Making teacher education count in everyday school practice," J. Clean. Prod., vol. 174, pp. 821-826, Jan. 2018, doi: 10.1016/j.jclepro.2017.10.263.

[26] C. Varghese, L. Vernon-Feagans, and M. Bratsch-Hines, "Associations between teacher-child relationships, children's literacy achievement, and social competencies for struggling and non-struggling readers in early elementary school," Early Child. Res. Q., vol. 47, pp. 124133, Apr. 2019, doi: 10.1016/j.ecresq.2018.09.005.

[27] I. Verner, K. Massarwe, and D. Bshouty, "Development of competencies for teaching geometry through an ethnomathematical approach," J. Math. Behav., vol. 56, pp. 1-14, Dec. 2019, doi: 10.1016/j.jmathb.2019.05.002.

[28] Z. C. Karababa and G. Çalışkan, "Teacher competencies in teaching Turkish as a foreign language," Procedia - Soc. Behav. Sci., vol. 70, pp. 1545-1551, Jan. 2013, doi: 10.1016/j.sbspro.2013.01.222.

[29] T. Nousiainen, M. Kangas, J. Rikala, and M. Vesisenaho, "Teacher competencies in game-based pedagogy," Teach. Teach. Educ., vol. 74, pp. 85-97, Aug. 2018, doi: 10.1016/ j.tate.2018.04.012.

[30] D. Farjon, A. Smits, and J. Voogt, "Technology integration of pre-service teachers explained by attitudes and beliefs, competency, access, and experience," Comput. Educ., vol. 130, pp. 81-93, Mar. 2019, doi: 10.1016/j.compedu.2018.1 1.010 .

[31] J. Nasongkhla and S. Sujiva, "Teacher competency development: Teaching with tablet technology through classroom innovative action cesearch (CIAR) coaching process," Procedia - Soc. Behav. Sci., vol. 174, pp. 992-999, Feb. 2015, doi: 10.1016/j.sbspro.2015.01.723.

[32] M. K. Kim, K. Xie, and S. L. Cheng, "Building teacher competency for digital content evaluation," Teach. Teach. Educ., vol. 66, pp. 309-324, Aug. 2017, doi: 10.1016/j.tate 2017.05.006
[33] H. Han, "Design and implementation of web-based English autonomous learning system," Int. J. Emerg. Technol. Learn., vol. 14, no. 6, pp. 18-26, 2019, doi: 10.3991/ijet.v14i06.9718.

[34] W. D. Sulistyo, U. Nafiáh, and Idris, "The development of E-PAS based on massive open online courses (MOOC) on local history materials," Int. J. Emerg. Technol. Learn., vol. 14, no. 9, pp. 119-129, 2019, doi: 10.3991/IJET.V14I09.1 0143 .

[35] J. Luo, "Teaching mode of thinking development learning based on mind mapping in the course of health fitness education," Int. J. Emerg. Technol. Learn., vol. 14, no. 8, pp. 192-205, 2019, doi: 10.3991/ijet.v14i07.10110.

[36] I. Arifin, B. Wibawa, and Z. Syahrial, "The role of facilitators in a collaborative online learning einvironment," International Journal of Innovative Technology and Exploring Engineering, vol. 8, no. 6c2, pp. 72-75, 2019, retrieved from: https://www.ijitee.org/wp-content/uploads/ papers/v8i6c2/F10140486C219.pdf

[37] Astuti, et al, "Developing Adobe Flash-based mathematics learning media for 7th grade students of junior high school," J. Phys.: Conf. Ser. 1188012098, pp. 1-14, doi:10.1088/1742-6596/1188/1/012098 